\title{
Integrating ecological, social and policy aspects to develop peatland restoration strategies in Orang Kayo Hitam Forest Park, Jambi, Indonesia
}

\author{
CHRISTINE WULANDARI, NOVRIYANTI NOVRIYANTI", DIAN ISWANDARU \\ Department of Forestry, Faculty of Agriculture, Universitas Lampung, Jl. Prof. Dr. Sri Soemantri Brojonegoro No.1 Gedong Meneng, Rajabasa, Bandar \\ Lampung 35141, Lampung, Indonesia. Tel.: +62-721-704946. `email: novriyanti.nov@ fp.unila.ac.id
}

Manuscript received: 9 August 2021. Revision accepted: 11 September 2021

\begin{abstract}
Wulandari C, Novriyanti N, Iswandaru D. 2021. Integrating ecological, social and policy aspects to develop peatland restoration strategies in Orang Kayo Hitam Forest Park, Jambi, Indonesia. Biodiversitas 22: 4158-4168. Peatlands play an essential role in delivering various ecosystem services, yet in many areas in Indonesia, peat forests have been deforested, degraded, and threatened by repeated fires. As such, restoration efforts need to be done. But these require various considerations, including ecological aspects such as type degradation conditions, water table, species selected for planting, and climates, socio-economic aspects like community's involvement, and policy aspects such as regulations and institutions at national and local levels. This study aimed to analyze peatland restoration strategies in Orang Kayo Hitam $(\mathrm{OKH})$ Forest Park, Jambi using the Strengths, Weaknesses, Threats, and Opportunities (SWOT) framework. The analysis was done by integrating multiple aspects such as policy, biodiversity conservation, and surrounding community participation. Data were collected using virtual ethnographic techniques due to the COVID-19 pandemic. Key informants (i.e., OKH Forest Park Unit area managers, NGOs, staff of national government, and university academics) and selected respondents were interviewed to identify and determine factors considered as internal (i.e., Strengths and Weaknesses) and external (i.e., Threats and Opportunities). This qualitative data was then analyzed using a SWOT approach through the IFE (Internal Factor Evaluation) and EFE (External Factor Evaluation) Matrix. The research findings showed that from 12 internal factors and 11 external factors, efforts to restore peatland ecosystems in Orang Kayo Hitam $(\mathrm{OKH})$ Forest Park had obtained very strong values in the biodiversity aspect. The SWOT matrix analysis showed values of $\mathrm{S}-\mathrm{W}=0.43$ and $\mathrm{O}-\mathrm{T}=0.16$ positioned in quadrant $\mathrm{I}$. This result suggests that the most powerful strategies can be developed aggressively from the factors of strengths and opportunities.
\end{abstract}

Keywords: Peatland conservation, peatland management, SWOT, Tahura Sekitar Tanjung, virtual ethnography

Abbreviations: OKH: Orang Kayo Hitam; BRGM: Peat and Mangrove Restoration Agency

\section{INTRODUCTION}

Peatland is a fragile ecosystem that hosts various rare plants and wildlife (Wösten et al. 2006). Peatland also plays a vital role in delivering ecosystem services, particularly maintaining hydrological function and as a carbon sink (Cole et al. 2015; Page et al. 1999; Yule 2010). Furthermore, peatland is highly important in climate change debates at a global and national level (Harrison et al. 2020). On a local scale, many communities are highly dependent on peatland for their sustainable livelihoods (Syahza et al. 2020).

Indonesia initially had 10,8\% of forest land (about 20,6 million ha) with peat ecosystems (often so-called peat forest). It is the largest tropical peatland in Southeast Asia (Gumbricht et al. 2017; Page et al. 2011), even the largest globally (BRG 2019; KLHK 2018; Miles et al. 2017). However, Indonesia peatland faces many challenges (Hergoualc'h et al. 2018), primarily because of deforestation and forest degradation, occurring since the 1980s (Miettinen et al. 2016; Wijedasa et al. 2018). The causes of peatland deforestation and degradation include transmigration, local population growth, and economic development (Deshmukh et al. 2020), resulting in almost half of the peat forest areas have been lost (Wahyunto et al. 2014), and now only 14.83 million ha of peat forest remained ( $\mathrm{Xu}$ et al. 2018).

Indonesian peatlands spread over the islands of Sumatra, Kalimantan, Sulawesi, and Papua. More than 7 million ha of peatlands (Murdiyarso et al. 2004) in Sumatra; these peatlands are forested or non-forested. Peatland in Sumatra includes Riau, South Sumatra, and Jambi (Wüst et al. 2007). Jambi Province has 621,089 ha of peatlands, or equal to $9.65 \%$ of total peatlands in Sumatra. Yet, this province contributes as one of the largest carbon sinks in Indonesia from the peat sector due to fires (Wahyunto et al. 2014; Nurdiana et al. 2016; BRG 2019). In Jambi Province in the last 15 years, there were 26,623 hotspots and 5,185 chance events (probable to be fire) with an $80 \%$ confidence level (Prasetyo et al. 2016). It implies that the entire Jambi peatlands have fire risks, including in crucial biodiversity conservation areas in Orang Kayo Hitam (OKH) Forest Park in Berbak.

Orang Kayo Hitam (OKH) Forest Park (Taman Hutan Raya Orang Kayo Hitam) is Indonesia's only conservation area with a type of peat swamp forest ecosystem. The OKH 
Forest Park has an area extent of $18,140.32$ ha based on SK.1973/MENLHK-PKTL/KUH/PLA.2/4/2017 Ministry of Environment and Forestry RI. Historically, based on RPJP (Long Term Management Plan) of OKH Forest Park for 2020-2030, in this conservation area ever live the specific plant species of peat forest, i.e., Gonystylus bancanus, Dyera sp., Shorea sp., Litsea sp., Gluta renghas, Tetramerista glabra, Campnosperma auriculata, Koompassia malaccensis. Here we also can find other species like Garcinia spp., Mangifera spp., some rattan species, and be a habitat of medicinal plant species like Eurycoma longifolia. This area also serves as a buffer zone or an "entrance" for Berbak Sembilang National Park. It also means that the destruction of the OKH Forest Park could harm the sustainability of Berbak Sembilang National Park. From 1997 to 2015, there were four fire events in the OKH Forest Park Unit area (Hamzah et al. 2019). The most extensive fires in 2015 have left more than $70 \%$ of the forest park to be open areas (Tamin et al. 2021) and just overgrown with weeds (Nurjanah et al. 2013; Tamin et al. 2019), making the landscape to become highly degraded. This condition requires serious efforts to restore peatland in the forest park to prevent loss of biodiversity and ecosystem services (Avagyan et al. 2017).

Various efforts to restore peat globally have been carried out, including in OKH Forest Park Unit area. Restoration of degraded peatland involves water management activities (Wösten et al. 2006), estimated the carbon sink (Anshari et al. 2021), rehabilitation using natural regeneration (Tamin et al. 2021), planting native plant species (Tata and Pradjadinata 2016) and non-native plant species (Nuroniah et al. 2021). It also engaged community participation (Budiman et al. 2020; Pratiwi et al. 2021; Thoha et al. 2018) and policy intervention
(Dohong et al. 2017). Several biotic and abiotic factors affect the success in peatland restoration, including climates incredibly long drought, peat topography, peatland drainage, presence of invasive species and shrubs, repeated fires, and risk of flooding (Dohong et al. 2018b; Lampela et al. 2017).

However, understanding the strengths and weaknesses of various peatland reforestation efforts is limited. One crucial issue is whether stakeholders and communities around peatland understand the challenges and opportunities of peatland reforestation activities. This study aimed to analyze peatland restoration strategies in Orang Kayo Hitam (OKH) Forest Park using strengths, weaknesses, threats, and opportunities (SWOT) framework. The analysis was based on multiple aspects such as policy, flora-fauna conservation, and surrounding community participation. OKH Forest Park is an excellent study context since it consists of peatland areas, most of which are in degraded conditions. This forest park also functions as a buffer zone for Berbak Sembilang National Park, implying that the degradation of the OKH Forest Park will pose threats to Berbak Sembilang National Park, especially threats related to fire.

\section{MATERIALS AND METHODS}

\section{Study period and area}

This study was conducted from May to July 2021. An Orang Kayo Hitam (OKH) Forest Park Unit area is this study area. It is geographically located at $1^{\circ} 16^{\prime} 46^{\prime \prime}-$ $1^{\circ} 29^{\prime} 41^{\prime \prime} \mathrm{S}$ and $103^{\circ} 59^{\prime} 5^{\prime \prime}-104^{\circ} 9^{\prime} 2^{\prime \prime} \mathrm{E}$ in Jambi Province. overview of this study area can be seen in Figure 1.
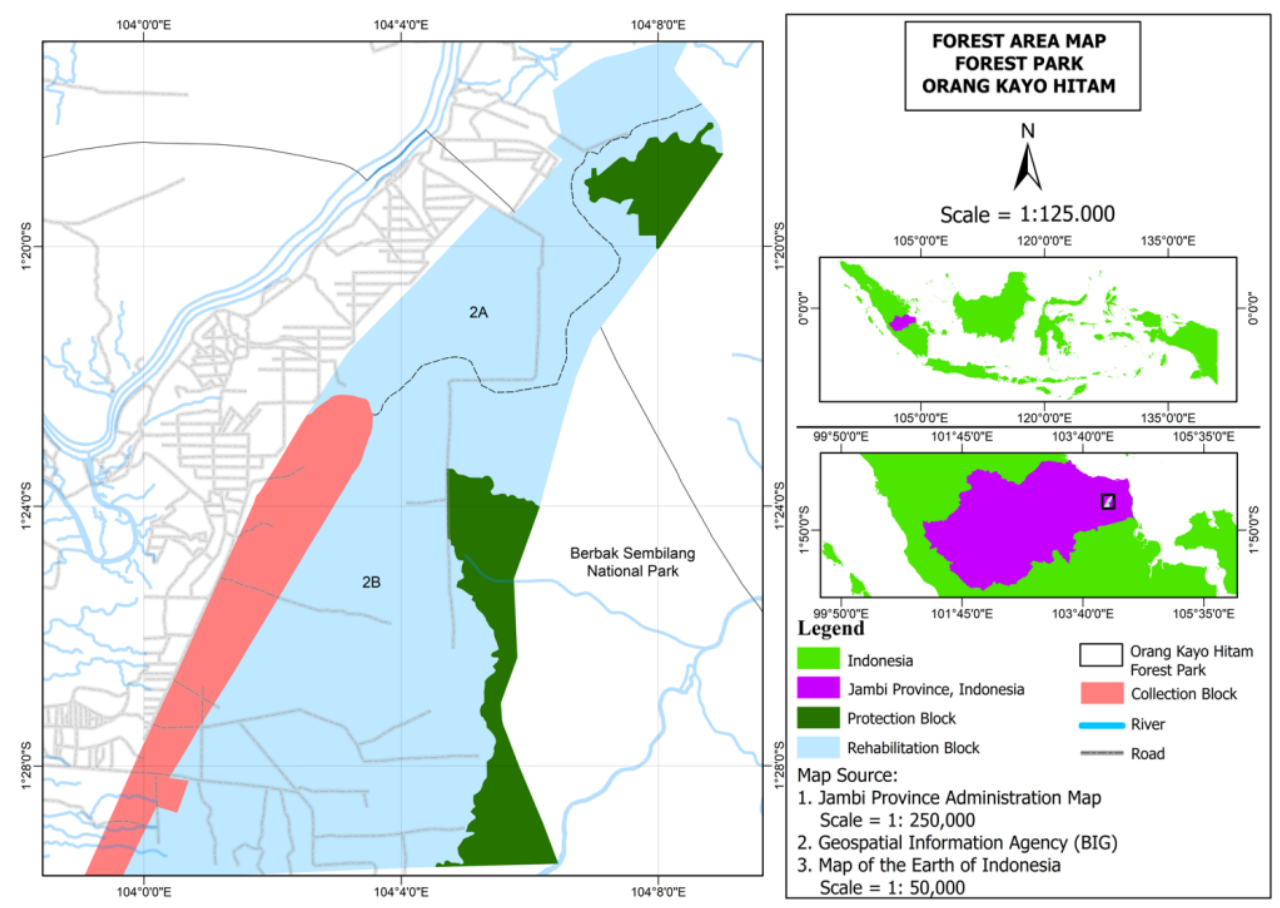

Figure 1. Research location in Orang Kayo Hitam Forest Park, Jambi Province, Indonesia 


\section{Data collection}

The data collected were related to peatland management. There are policies regarding forest park (Tahura) in Indonesia, community participation, and biodiversity aspects which are important considerations in peatland restoration in OKH Forest Park Unit area. These data were obtained through the Virtual Ethnography interview technique (Angelone 2019; Hine 2000). This method is gaining popularity and is widely developed, especially in social research regarding travel restrictions due to the COVID-19 pandemic. This method has the Strength that it can penetrate space and time (Crichton and Kinash 2003).

Virtual interviews were conducted with stakeholders related to peatland management, ranging from policy aspects, community involvement, to biodiversity enrichment, both in Jambi Province and on a national scale. Relevant stakeholders at Jambi provincial level were OKH Forest Park Unit (UPTD Tahura), Jambi University, and NGO KKI Warsi. In contrast, stakeholders at the national level were the Peat and Mangrove Restoration Agency (BRGM). Behind four stakeholders, the public who have visited the peat ecosystem has also been a source of information and then referred to as respondents. The data was general knowledge about the peat ecosystem, categorized as Strength, Weak, Opportunity, and Threats in OKH Forest Park Unit area management based on social, economic, social, and institutional variables. The respondents were assumed to have knowledge and experience about peatland, so their answers were regarded as not biased. The total number of respondents from the public was 231 people.

\section{Data analysis}

The formulation of strategic recommendations for conservation and reforestation of peatland in the $\mathrm{OKH}$ Forest Park Unit area was determined using SWOT analysis (Bolte et al. 2009; Helms and Nixon 2010). This analysis evaluated the key aspects of peatland management in the OKH Forest Park Unit area throughout identified internal and external factors. The obtained data were categorized based on strengths, weaknesses, opportunities, and threats to develop management strategies for peatland reforestation. The stages are as follows (Scolozzi et al. 2014; Yam 2020):

\section{Determination of internal and external factors}

The interview results of the respondents were identified and grouped into internal and external factors. This stage used the Matrices of Internal Factor Evaluation (IFE) and External Factor Evaluation (EFE). All data classified as strengths and weaknesses were grouped into internal factors, while the interviews data classified as threats and opportunities were grouped into external factors (Figure 2).

\section{Scoring analysis of plausible strategies}

This stage was aimed to develop all plausible strategies for peatland restoration in OKH Forest Park. The external and internal factors were combined to produce recommended strategies. The result of this stage was the score obtained from each SWOT factor by multiplying the scoring value (b) and rank (r).

Scoring value (b). In the SWOT framework, the horizontal indicators (strengths and weaknesses) and vertical indicators (opportunities and threats) were given a weight between 1 to 4 for each indicator with the following meaning: (i) $1=$ horizontal indicators are considered to the least important than vertical indicators, (ii) $2=$ horizontal indicators are considered to be more important than vertical indicators, (iii) $3=$ horizontal indicators are considered to be quite important than vertical indicators, (iv) $4=$ horizontal indicators are considered to be the most important than vertical indicators.

Ranking (r). Each SWOT factor was ranked on a scale of 1 to 4 . For example, the strength factor has the following values: (i) $4=$ very strong, (ii) $3=$ strong, (iii) $2=$ low strength, (iv) $1=$ very low strength

The IFE and EFE matrices analysis results were processed on a SWOT diagram or quadrant (Figure 3). The SWOT quadrant in SWOT analysis is a tool for systematically identifying various factors and describing how the opportunities and threats are matched to their strengths and weaknesses. Based on this SWOT analysis, it will be seen what strategy was decided to be developed by following four Strategies (Figure 4).

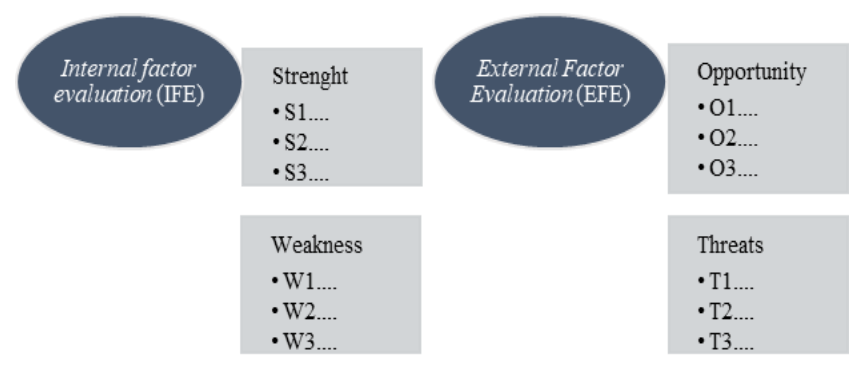

Figure 2. Data clustering in the first stage of SWOT analysis

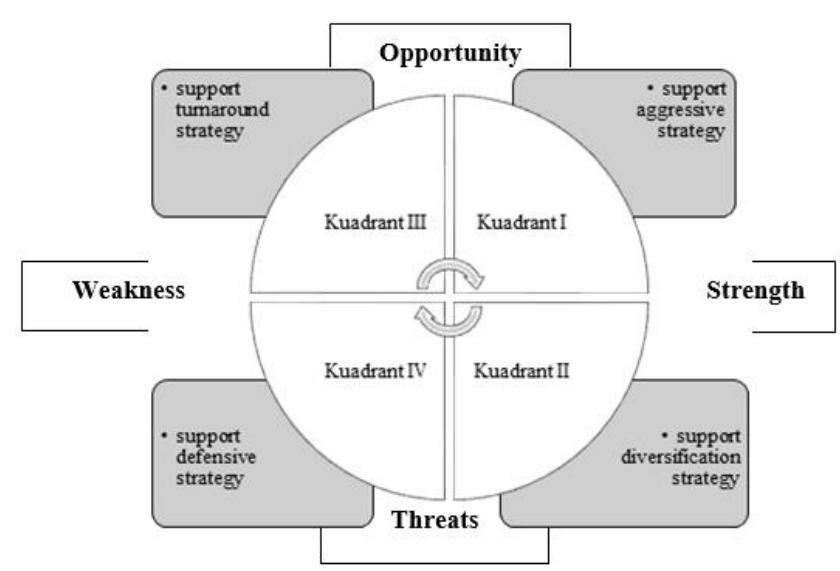

Figure 3. The general framework of SWOT analysis and the division of the quadrants. 


\section{RESULTS AND DISCUSSION}

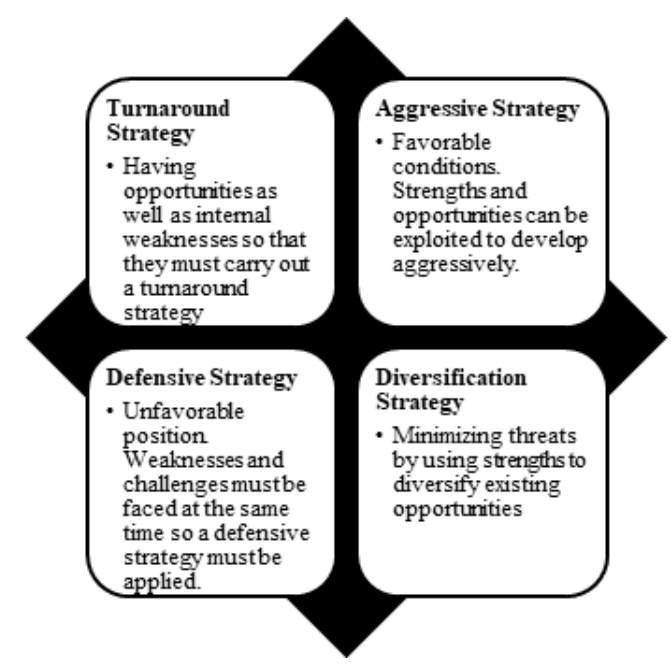

Figure 4. Formulation of plausible strategies developed from the result of the SWOT analysis (modified from Rangkuti, 2013).
The research findings in Table 1 show six Strengths and six Weaknesses (Internal Factors) related to peatland reforestation in the $\mathrm{OKH}$ Forest Park Unit area. Meanwhile, there are five Opportunities and six Threats from External Factors that are greatly important and affect peatland restoration. Both Internal and External Factors cover the aspects of biodiversity, policies, community participation, and institution.

\section{Internal Factors: Strengths and Weaknesses in Peatland Reforestation in OKH Forest Park Unit area}

Efforts to improve peatland governance continue to be carried out by the Indonesian government together with relevant stakeholders. One of these efforts is compiling and ratifying certain policy products regarding peatland management at the primary and secondary levels (dealing with technical issues) (Figure 5). According to this study, the policy aspect has a 0.2041 SWOT score (Figure 6) (fifth rank in the Strength list). Respondents did not state any Weaknesses in policy implementation by OKH Forest Park Unit area.

Table 1. List of strengths, weaknesses, opportunities, and threats (SWOT) related to peatland reforestation in OKH Forest Park, Jambi, Indonesia

\begin{tabular}{|c|c|c|}
\hline Factor & Aspect of study & SWOT score \\
\hline 1. $\quad$ Strength & & 1.54 \\
\hline 1. There is availability of tree provenance & Biodiversity & 0.48 \\
\hline 2. OKH Forest Park is rich in biodiversity and contains endemic species & Biodiversity & 0.30 \\
\hline There is interest of local communities to manage peatland & Community Participation & 0.22 \\
\hline $\begin{array}{l}\text { 4. There are institutions of peatland management from national to site } \\
\text { levels }\end{array}$ & Institution & 0.21 \\
\hline 5. There are policies regarding peatland management & Policy & 0.20 \\
\hline 6. There is access to management in OKH Forest Park Unit area & Community Participation & 0.12 \\
\hline 2. Weakness & & 1.11 \\
\hline 1. Community knowledge about peatland management is limited & Community Participation & 0.05 \\
\hline 2. Reforestation area is remote from the seed provenance & Biodiversity & 0.35 \\
\hline 3. Limited knowledge of OKH Forest Park Unit area staff & Institution & 0.05 \\
\hline $\begin{array}{l}\text { 4. Many of the boundaries of the OKH Forest Park Unit area are } \\
\text { damaged or missing }\end{array}$ & Institution & 0.23 \\
\hline 5. Limited number of staff in OKH Forest Park Unit area & Institution & 0.18 \\
\hline $\begin{array}{l}\text { 6. Peat management institutions in general are not yet strong, national } \\
\text { level institutions are ad hoc }\end{array}$ & Institution & 0.24 \\
\hline 3. Threats & & 1.48 \\
\hline 1. Conflicts between local community and OKH Forest Park Unit area & Community Participation & 0.24 \\
\hline 2. Encroachment & Biodiversity & 0.31 \\
\hline Fires occurs frequently & Biodiversity & 0.32 \\
\hline 4. Illegal hunting of animals & Biodiversity & 0.22 \\
\hline 5. Land conversion & Biodiversity & 0.18 \\
\hline 6. Law enforcement & Policy & 0.21 \\
\hline 4. Opportunity & & 1.32 \\
\hline 1. Community willingness to be a partner of OKH Forest Park Unit area & Community Participation & 0.27 \\
\hline $\begin{array}{l}\text { 2. Diversity of flora and fauna species, including species that have the } \\
\text { ability to resprout after a fire }\end{array}$ & Biodiversity & 0.35 \\
\hline 3. The existence of regulations from local to national levels & Policy & 0.20 \\
\hline 4. The existence of village fund (Dana Desa) from state budget & Policy & 0.19 \\
\hline 5. Wetting peatland can make it suitable as a place to grow species & Biodiversity & 0.31 \\
\hline Grand total & & 5.44 \\
\hline
\end{tabular}



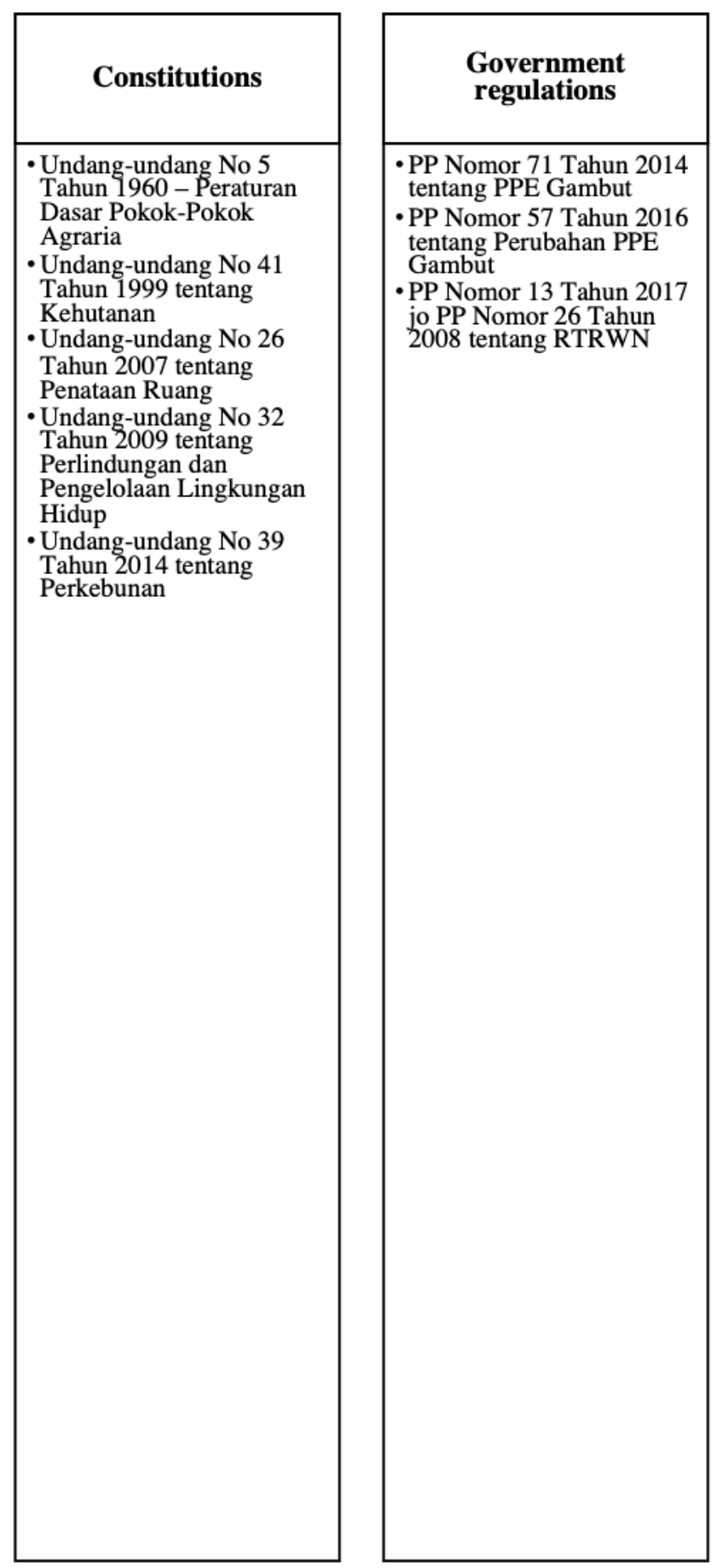

\begin{tabular}{|l|}
\hline \multicolumn{1}{|c|}{ Ministerial } \\
Regulations and \\
Decrees \\
\hline - Permen No. 60 Tahun \\
2019 tentang Tata Cara \\
Penyusunan, Penetapan, \\
dan Perubahan Rencana \\
Perlindungan dan \\
Pengelolaan Ekosistem \\
Gambut (RPPEG) \\
- Permen No 14 Tahun \\
2017 - Inventarisasi dan \\
Penetapan Fungsi Gambut \\
- Permen No 15 Tahun \\
2017 - Pengukuran Muka \\
Air Tanah Gambut \\
-Permen No 16 Tahun \\
2017 - Pedoman Teknis \\
Pemulihan Fungsi \\
Ekosistem Gambut \\
-Permen No 17 Tahun \\
2017 - Pembangunan \\
Hutan Tanaman Industri \\
-Permen No 77 Tahun \\
2015 - Tata Cara \\
Penanganan Areal yang \\
Terbakar dalam Izin \\
Usaha Pemanfaatan Hasil \\
Hutan Pada Hutan \\
Produksi. \\
- Permen No 83 Tahun \\
2016 - Perhutanan Sosial \\
- Kepmen Menteri LHK \\
No. 246 Tahun 2020 \\
tentang Rencana \\
Perlindungan Ekosistem \\
Gambut (RPPEG) \\
Nasional Tahun 2020- \\
2049 \\
- Kepmen No 129 Tahun \\
2017 - Penetapan Peta \\
Kesatuan Hidrologis \\
Gambut Nasional \\
- Kepmen No 130 Tahun \\
2017- Penetapan Peta \\
Fungsi Ekosistem Gambut \\
Nasional \\
- Kepmen No 295 Tahun \\
2017 - Penetapan Peta \\
Fungsi Ekosistem Gambut \\
Skala 1:50.000 Pada KHG \\
Pulau Bengkalis, KHG \\
Pulau Tebing Tinggi, \\
KHG Sungai Kampar - \\
Sungai Gaung, KHG \\
Sungai Gaung - Sungai \\
Batang Tuaka, dan KHG \\
Sungai Kapuas - Sungai \\
Terentang. \\
\hline
\end{tabular}

\begin{tabular}{|l|}
\hline Regulations and \\
Decrees of the \\
Directorate General \\
\hline -Perdirjen P18 PPKL \\
Tahun 2019 tentang \\
Pedoman Teknis \\
Pengolahan Data Spasial \\
Karakteristik Ekosistem \\
Gambut \\
•Perdirjen PPKL Nomor \\
P.3 Tahun 2018- \\
Pedoman Pembangunan \\
Infrastruktur Pembasahan \\
Untuk Pemulihan Gambut \\
•Perdirjen PPKL Nomor \\
P.4 Tahun 2018 - \\
Pedoman Tugas \\
Pembantuan Restorasi \\
Gambut 2018 \\
•Perdirjen PPKL Nomor \\
P.5 Tahun 2018 - \\
Petunjuk Teknis \\
Penyusunan Dokumen \\
Rencana Pemulihan \\
Ekosistem Gambut dan \\
Usulan Titik Penataan \\
Tinggi Muka Air Tanah \\
Manual, Titik \\
Pemasangan Alat \\
Pengukur Tinggi Muka \\
Air Tanah Otomatis serta \\
Titik Stasiun Pemantauan \\
Curah Hujan Bagi \\
Penanggung jawab Usaha \\
dan/atau Kegiatan \\
-Perdirjen PPKL Nomor \\
P.10 Tahun 2018 - \\
Pedoman Penilaian \\
Keberhasilan Pemulihan \\
Ekosistem Gambut bagi \\
Usaha dan/atau Kegiatan \\
-Keputusan Dirjen PPKL \\
Nomor SK.40 Tahun \\
2018 - Penetapan Status \\
Kerusakan Ekosistem \\
Gambut \\
\\
\\
\end{tabular}

Figure 5. Indonesian laws and regulations regarding peatland management

Aside from the policy aspect, there are two Strengths and one Weakness identified from another Internal side, i.e., biodiversity distinctiveness possessed in the peat ecosystem (code B on Figure 6). These Strengths are a) the availability of tree provenance and b) species endemicity in the peat ecosystem. Variable the availability of tree provenance has the greatest Strengthwith almost 0.5 points score (black arrow). Meanwhile, endemicity related to the variety of specific species on peat ecosystems and being a force to determine integrated management strategies has the second-highest score. 


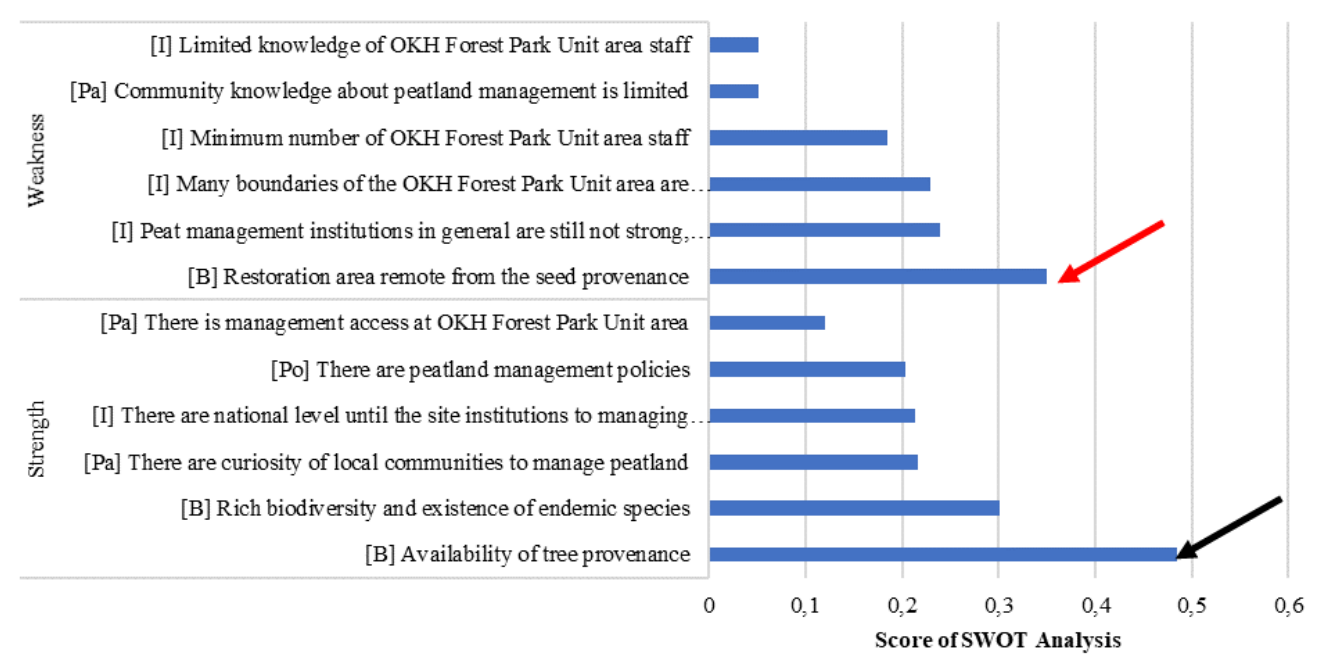

Figure 6. Score of SWOT analysis for internal factors. The black and red arrows are to show contradictions in internal factors in the efforts to restore peat ecosystems from a biodiversity perspective. Notes: $\mathrm{B}=$ biodiversity, $\mathrm{Po}=$ policy, $\mathrm{Pa}=$ community participation, and $\mathrm{I}=$ institutional

On the other hand, the biodiversity aspect needs attention because the research findings show contradictions on both, as shown in Figure 6. These research findings the seed bank area is available in the OKH Forest Park, and it also has the highest score on the Strength variable. Unfortunately, the study analysis indicates remote seed provenance location from the reforestation area (red arrow) will be the most significant Weakness for the reforestation efforts. If the seed source's origin is farther away, it will make it more difficult for the species in disturbed areas to adapt, but there is great hope because the original tree is still there and growing. Moreover, peatland is a unique ecosystem; not all species can live in waterlogged conditions, let alone in the acidic water of peat swamp (Dohong et al. 2018a; Gumbricht et al. 2017). This condition requires the ability of remaining native species to recover. It means efforts are needed to develop several seed sources in strategic locations in the OKH Forest Park Unit area. In addition, the suitability of species, especially those related to endemics and their provenance, is essential because it relates to how ecosystems can increase resilience and recover after fire disturbances (Bolte et al. 2009).

From an institutional perspective, there is only one Strength in peatland restoration, namely local and national institutions, whose main task and function are to manage the peat. On the other hand, three variables are considered Weaknesses, a) limited knowledge of OKH Forest Park Unit area staff on managing peat, b) the limited number of the management staff of OKH Forest Park Unit, and c) several OKH Forest Park Unit area boundaries marks are lost.

Last but not least is the community participation aspect which shows there are two strengths and one Weakness. The Strengths of this aspect are a) interest from local people to participate in managing peat; $b$ ) there is access to community management within the OKH Forest Park Unit area. Meanwhile, the Weaknesses limited knowledge of the surrounding community regarding peat ecosystem management techniques.

Knowledge is considered as one of the crucial aspects in the successful management of forests and ecosystems. Knowledge, especially those containing local wisdom, can act as a control to overexploitation (Bender et al. 2014) because the rules and taboos serve as guidance in social community activities (Bendsen and Motsholapheko 2003; Halim et al. 2012). Thus, knowledge can also help accelerate the recovery of damaged ecosystems because the relationship between humans and nature has been formed from a long history manifested in various cultural rituals (Bendsen and Motsholapheko 2003; Halim et al. 2012). Community knowledge organized in traditional institutions can be considered in determining biodiversity conservation policies (Halim et al. 2012).

Unfortunately, these findings indicate that the knowledge possessed by both community and management staff of the OKH Forest Park Unit area is minimal, with a weakness score of 0.0512 (very low). It shows that its impact on the development of peatland conservation strategies is also relatively small. Knowledge must be sufficient to ensure the sustainability of an ecosystem (Bartlett et al. 2017). The inside of the surrounding community and peat managers at the site level should be high. The limited knowledge of managing peat in a sustainable manner combined with the lack of staff can hurt the sustainability of the OKH Forest Park Unit area. Thus, it is necessary to increase the knowledge of the community and managers (UPTD Tahura OKH staff) regarding sustainable peatland management based on specific field conditions through intensive and structured counseling, training, or comparative studies. The type of training needed to increase skills, knowledge, and attitude (SKA) varies based on individual status and the length of time a community group has been established (Wulandari and Kurniasih 2019). Efforts to increase this knowledge must 
be guided by the Minister of Environment and Forestry Regulation P.35/MENLHK/SETJEN/KUM.1/3/2016 regarding the purpose of establishing Forest Park Area for the preservation of the natural resources, including flora and fauna biodiversity conservation by considering the social and economic aspects of the surrounding community.

In the context of the OKH Forest Park Unit area management, the manager's knowledge, which is a weakness factor, is also related to other weaknesses, namely the frequent loss of area boundary markings. If these conditions are not addressed immediately, the number of missing boundary markers will undoubtedly impact increasing the encroached area because people do not know the actual boundaries of the OKH Forest Park Unit area (Ambarasti 2016). To anticipate and minimize conflicts due to this condition, the improvement of the OKH Forest Park Unit area boundaries must be carried out immediately, and participation of the surrounding community needs to be encouraged. Supports by the surrounding community in conserving $\mathrm{OKH}$ Forest Park Unit area are important to ensure sustainability. However, to involve the community, there must be a distinct advantage they can get; for example, their living needs to be met from forest products generated from the forest park (Asmin et al. 2019; Ward et al. 2021; Wulandari et al. 2018; Wulandari and Kurniasih 2019).

The legality of institutions to do best practice on sustainable peatland management. Besides community participation, relevant institutions and local village government participation are also important. According to one of the key informants, management institution's appropriateness is needed to achieve forestry development goals. The existence of peatland management authorities at the national level, such as the Peat and Mangrove Restoration Agency (BRGM), and at the local level, like the OKH Forest Park Unit area, is expected to support the implementation of OKH Forest Park Unit area programs because there are official. Apart from these two institutions, there are other institutions, such as NGOs and donors, whose work in peatland management. For the next step, there is a need for coordination and cooperation between these institutions because, based on the SWOT analysis of this study, it is known that the OKH Forest Park Unit area needs various development programs to ensure its sustainability. Cooperation with other institutions can affect the sustainability of forest conservation programs (Wulandari and Inoue 2018). When the coordination and collaboration among the institutions have happened, the various weaknesses found from this research can be included as work programs for these institutions.

\section{External Factors: Threats and Opportunities in Peatland Reforestation in OKH Forest Park Unit Area}

On a national scale, BRGM has stated that canalization is the leading cause of peatland degradation, both peat with a protection function and a cultivation function. Peatland degradation is primarily caused by the highly human activities for subsistence needs and commercial exploitation. The entire discussion process with specific stakeholders in this study, including information from the Head of the OKH Forest Park Unit area, also agreed on this point, suggesting that all the threats that emerged were not necessarily derived from natural factors (Figure 7).

According to the study findings in Figure 7, the biggest threats to peatland management and reforestation are fires and land encroachment. These study findings also follow Dohong et al. (2017) state that the increasing intensity of fires and the quantity of area burned are exacerbated by weather and climatic conditions (Syaufina and Hafni 2018). The threat of land conversion is not distinguishable (lowest $\mathrm{T}$ score) because most of the peat area is outside the conservation area. The Directorate of the Peat Damage Control Republic of Indonesia, Ministry of Environment and Forestry, noted more than $75 \%$ of peat is a cultivation functions area. In contrast, peat with protected function areas are located in unlicensed land, and some are in other land uses (APL). The engagement strategy is also essential to do with this type of land conversion to drainage-based systems to encourage the sustainability and integration of peatland management (Evers et al. 2017).

Nevertheless, threats to peatland in conservation areas such as the OKH Forest Park still exist. The location of the OKH Forest Park Unit area is very close to community settlements, and it is a buffer zone for Berbak Sembilang National Park. High pressure also occurs on this conservation area because it shares a boundary with an oil palm plantation. Most of the threats appear to have suppressed the biodiversity aspect. The relevant institutions must prioritize the biodiversity conservation efforts in preparing the OKH Forest Park development program with various supporting opportunities. So the degraded areas can be recovered as stated in the existing policy, Minister of Environment and Forestry Regulation Number P.35/2016 concerning Procedures for Compiling Management Plans for Indonesian Nature Reserve Area (KSA) and Nature conservation area (KPA).

\section{Conservation management strategy to peatland reforestation development}

Fortunately, despite the threats, the peatland reforestation efforts have an excellent chance to be developed into a strategy. There are two Opportunities in favor of biodiversity, two Opportunities on policy, and one Opportunity for increasing community participation. From a biodiversity conservation perspective, rewetting can be an effort for species recovery. Also, naturally, peat species can resprout after fire. These two things are important for accelerating the recovery of degraded peat ecosystems, accompanied by national policies that favor local communities, as stated by key informants. But besides that, the community collectively also needs to develop policies at the local level to increase the sense of ownership of the OKH Forest Park. The community will participate independently (Asmin et al. 2019; Avagyan et al. 2017; Wulandari and Inoue 2018). Some people feel that national policies may harm their economy (Ward et al. 2021); engagement with multi-stakeholders must become a priority area to study. 


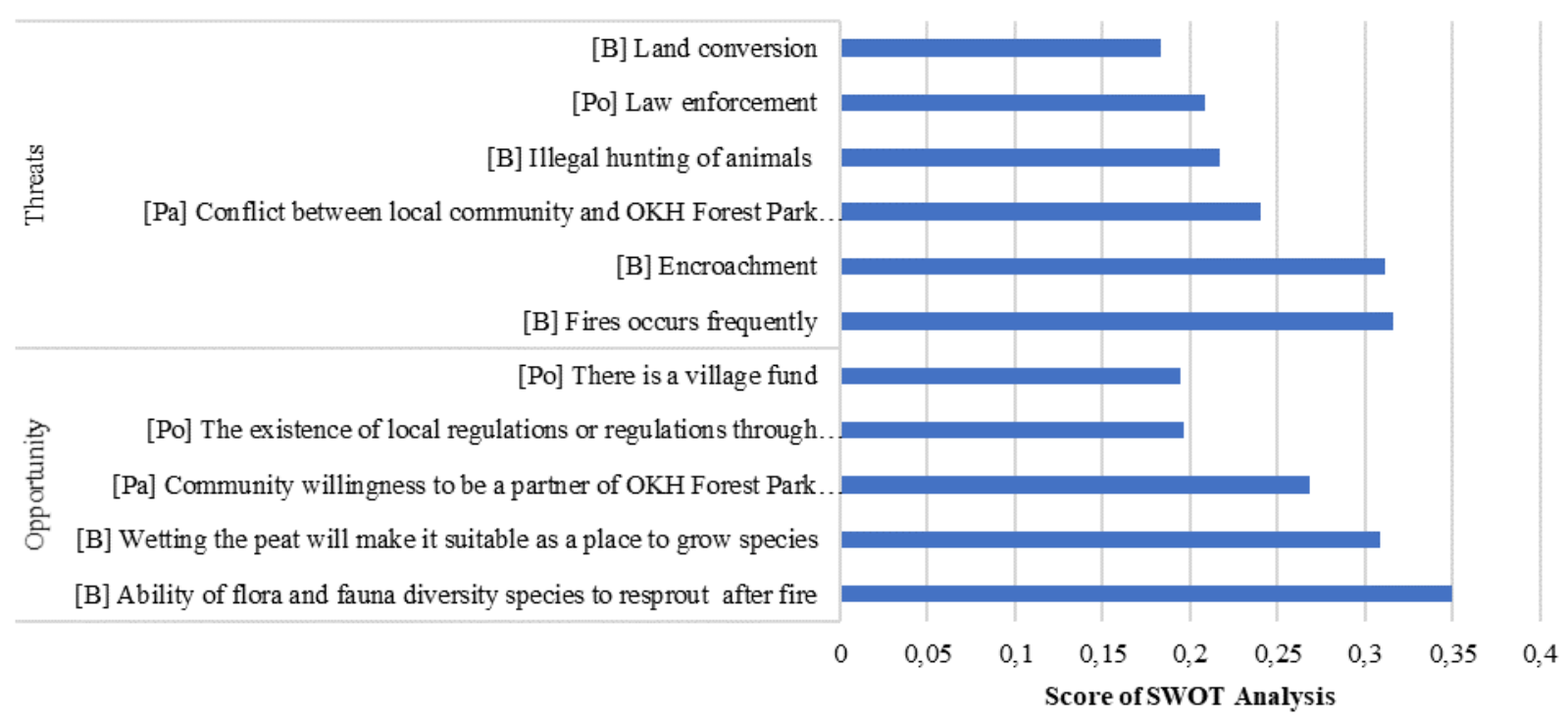

Figure 7. Score of SWOT analysis for external factors. Notes: $\mathrm{B}=$ biodiversity, $\mathrm{Po}=$ policy, $\mathrm{Pa}=$ community participation, and $\mathrm{I}=$ institutional

\section{Conservation management strategy to peatland reforestation development}

The differences in the internal and external factors in OKH Forest Park reforestation efforts, as presented in Figure 8 , are 0.43 and 0.16 . There are no negative factors, so the final result lies in quadrant I, meaning that the strategies to support peat conservation in the OKH Forest Park will be carrying up from Strength and Opportunity variables.

It is favorable where the peatland institution can simultaneously exploit Strengths and Opportunities to accelerate restoration in the $\mathrm{OKH}$ Forest Park. Unfortunately, only one Strength factor is considered strong enough even though the value is still less than 2 , namely the availability of tree provenance in the $\mathrm{OKH}$ Forest Park. The rest variables in each factor are weak. This result implies that so far, the efforts that have been made are not vital to achieve peat reforestation objectives (see Figure 9). Thus, an appropriate strategy is needed to increase conservation efforts in the OKH Forest Park utilizing progressive and aggressive integration between Strength and Opportunity factors (Rangkuti 2013).

This discourse has resulted in various National techniques and policy interventions and a severe social engagement effort (Dohong et al. 2017), including the OKH Forest Park Unit Area. A key BRGM informant stated that community involvement's social and economic aspect is manifested in national policy through Independent Village Cares for Peat (DMPG). Other activities include infrastructure development, peat rewetting activities (IPG), revegetation demonstration plots, construction of Field Schools, and demonstration plots of no-burning land preparation (PLTB), and Production Seed Areas involve local community groups as a whole. Specifically for rewetting activities, some communities may not want to be involved. Still, most of them support it because there is an assumption that this activity has no impact on their agricultural output (Ward et al. 2021). However, research findings indicate that integration strategies must be carried out progressively and aggressively, mainly to recover biodiversity (Figure 10).

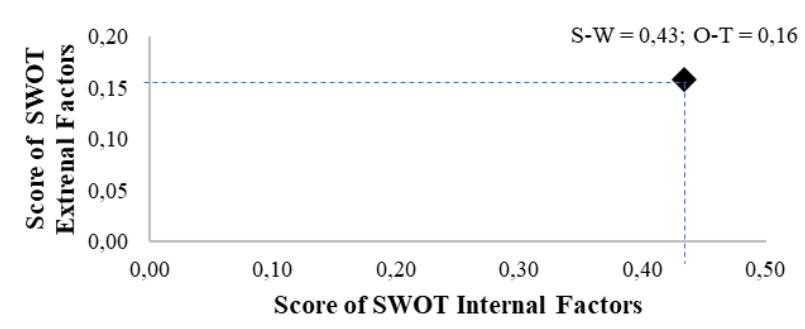

Figure 8. Score of SWOT from internal and external factors

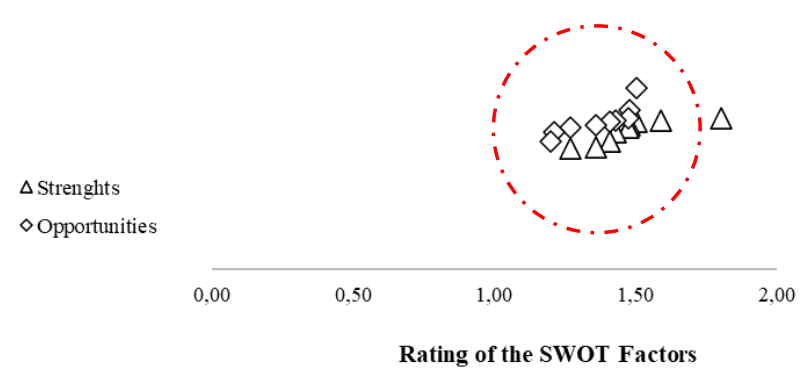

Figure 9. Distribution of Strength and Opportunity factor scores that indicate their level of importance in restoration of peatland in OKH Forest Park 


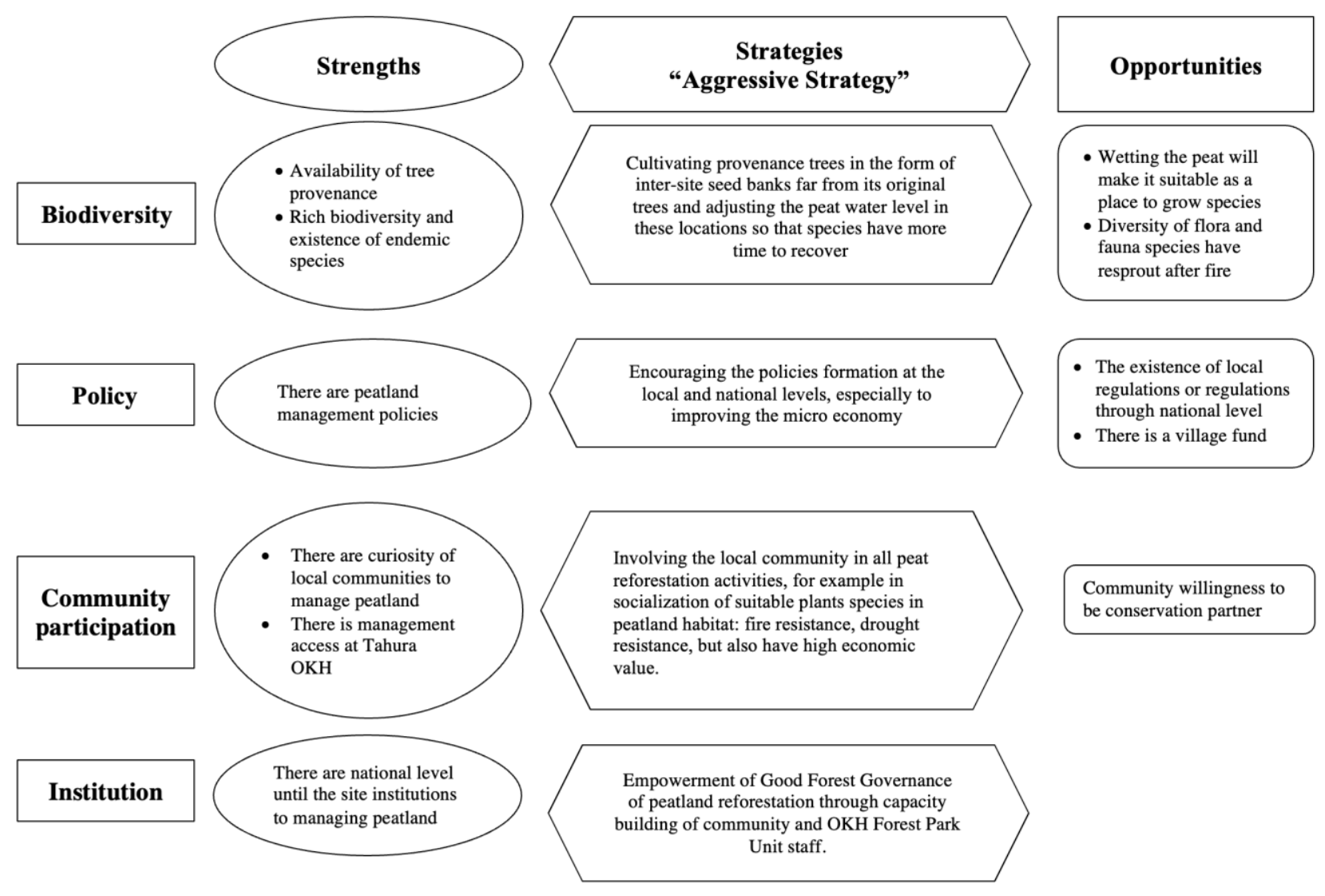

Figure 10. The diagram of integrated of peatland management and restoration

These strategies include (i) cultivating provenance trees in the form of inter-site seed banks far from their original trees and adjusting the peat water level in these locations so that species have more time to recover; (ii) encouraging policy forums at local and national levels to improve micro-economy and clearly on benefit-sharing; (iii) involving the local community in all peat reforestation activities, for example in the socialization of suitable plants species in peatland habitat that are fire resistance, drought resistance, but also has high economic value; and (iv) empowerment of good forest governance of peatland reforestation through capacity building of community and OKH Forest Park Unit staff.

In conclusion, based on the SWOT analysis, it found that so far, the efforts to support peatland reforestation in the OKH Forest Park Unit Area have not been sufficient. Therefore, we recommend that the peatland reforestation strategy in the $\mathrm{OKH}$ Forest Park Unit Area utilize the Strengths and Opportunities progressively and aggressively. According to the purpose of the OKH Forest Park Unit Area establishment, the strategy implemented must support efforts to conserve biodiversity and forest resources and forest sustainability.

\section{ACKNOWLEDGEMENTS}

Thank the Ministry of Education, Culture, Research, and Technology of the Republic of Indonesia through the
2019 Basic Research Grant scheme for the financial support. We also thank four key stakeholders, i.e., Head of OKH Forest Park Unit Area, BRGM Republic of Indonesia, Jambi University, and NGO of KKI Warsi, for the data provided.

\section{REFERENCES}

Ambarasti K. 2016. Konflik penggunaan lahan di kawasan hutan pada Wilayah Kesatuan Pengelolaan Hutan Produksi (KPHP) Model Banjar. Jurnal Hutan Tropis 4 (2): 167-179. [Indonesian]

Angelone L. 2019. Virtual ethnography: The post possibilities of not being there. Mid-Western Edu Res 31 (3): 275-295.

Anshari GZ, Gusmayanti E, Novita N. 2021. The use of subsidence to estimate carbon loss from deforested and drained tropical peatlands in Indonesia. Forests 12 (6): 732. DOI: 10.3390/f12060732

Asmin F, Darusman D, Ichwandi I, Suharjito D. 2019. Mainstreaming community-based forest management in west sumatra: Social forestry arguments, support, and implementation. For Soc 3 (1): 77-96. DOI: 10.24259/fs.v3i1.4047

Avagyan A, Baker E, Barthelmes A, Velarde HC, Dargie G, Guth M, Hergoualc'h K, Johnson L, Joosten H, Kieft J, Kopansky D, Miles L, Minayeva T, Montanarella L, Nuutinen M, van Paddenburg A, Peters J, Richard J, Salathe T, Schoolmeester T, Silvius M. 2017. Smoke on Water-Countering Global Threats From Peatland Loss and Degradation. United Nations Environment Programme and GRIDArendal, Nairobi.

Bartlett AG, Kanowski PJ, van Kerkhoff L, Byron RN. 2017. Identifying factors that influence the success of forestry research projects implemented in developing countries: Case study results from Vietnam. Forestry Oxford University Press 90 (3): 413-425. DOI: 10.1093/forestry/cpw067 
Bender MG, Machado GR, de Azevedo Silva PJ, Floeter SR, MonteiroNetto C, Luiz OJ, Ferreira CEL. 2014. Local ecological knowledge and scientific data reveal overexploitation by multigear artisanal fisheries in the Southwestern Atlantic. PLoS One 9 (10): e110332 DOI: 10.1371 /journal.pone.0110332

Bendsen H, Motsholapheko MR. 2003. The Role of Indigenous Technical Knowledge in Natural Resource Management in Ngamiland

Bolte A, Ammer C, Löf M, Madsen P, Nabuurs GJ, Schall P, Spathelf P, Rock J. 2009. Adaptive forest management in central Europe: Climate change impacts, strategies and integrative concept. Scandinavian J For Res 24 (6): 473-482. DOI: 10.1080/02827580903418224

BRG. 2019. Rencana Tindakan Tahunan Restorasi Gambut Provinsi Jambi. Jakarta. [Indonesian]

Budiman I, Januar R, Daeli W, Hapsari RD, Sari EN. 2020. Designing the special pilot economic zone on peatlands. Jurnal Geografi Lingkungan Tropik 4 (1): 1-23. DOI: 10.7454/jglitrop.v4i1.73

Cole LES, Bhagwat SA, Willis KJ. 2015. Long-term disturbance dynamics and resilience of tropical peat swamp forests. J Ecol 103 (1): 16-30. DOI: 10.1111/1365-2745.12329

Crichton S, Kinash S. 2003. Virtual ethnography: Interactive interviewing online as method. Canadian J Learn Technol 29 (2): EJ1073763. DOI: 10.21432/T2W02T

Deshmukh CS, Julius D, Evans CD, Nardi, Susanto AP, Page SE, Gauci V, Laurén A, Sabiham S, Agus F, Asyhari A, Kurnianto S, Suardiwerianto Y, Desai AR. 2020. Impact of forest plantation on methane emissions from tropical peatland. Global Change Biol 26 (4): 2477-2495. DOI: $10.1111 / \mathrm{gcb} .15019$

Dohong A, Abdul Aziz A, Dargusch P. 2018a. A review of techniques for effective tropical peatland restoration. Wetlands 38 (2): 275-292. DOI: $10.1007 / \mathrm{s} 13157-018-1017-6$

Dohong A, Aziz AA, Dargusch P. 2017. A review of the drivers of tropical peatland degradation in South-East Asia. Land Use Policy 69: 349-360. DOI: 10.1016/j.landusepol.2017.09.035

Dohong A, Aziz AA, Dargusch P. 2018b. Carbon emissions from oil palm development on deep peat soil in Central Kalimantan Indonesia. Anthropocene 22: 31-39. DOI: 10.1016/j.ancene.2018.04.004

Evers S, Yule CM, Padfield R, O'Reilly P, Varkkey H. 2017. Keep wetlands wet: The myth of sustainable development of tropical peatlands-implications for policies and management. Global Change Biol 23 (2): 534-549. DOI: 10.1111/gcb.13422

Gumbricht T, Roman-Cuesta RM, Verchot L, Herold M, Wittmann F, Householder E, Herold N, Murdiyarso D. 2017. An expert system model for mapping tropical wetlands and peatlands reveals South America as the largest contributor. Global Change Biol 23 (9): 3581 3599. DOI: $10.1111 / \mathrm{gcb} .13689$

Halim AA, Jawan JA, Ismail SR, Othman N, Ibrahim NN. 2012 Indigenous knowledge and biodiversity conservation in Sabah, Malaysia. Int J Soc Sci Human 2 (2): 159-163. DOI: 10.7763/IJSSH.2012.V2.88

Hamzah H, Napitupulu RRP, Muryunika R. 2019. Contribution of soil and under storey carbon stock in post burned peat ecosystem as carbons storage on tropical land. Jurnal Silva Tropika 3 (1): 108-117.

Harrison ME, Ottay JB, D'Arcy LJ, Cheyne SM, Anggodo, Belcher C, Cole L, Dohong A, Ermiasi Y, Feldpausch T, Gallego-Sala A, Gunawan A, Höing A, Husson SJ, Kulu IP, Soebagio SM, Mang S, Mercado L, Morrogh-Bernard HC, Page SE, Priyanto R, Ripoll Capilla B, Rowland L, Santos EM, Schreer V, Sudyana IN, Taman SBB, Thornton SA, Upton C, Wich SA, van Veen FJF. 2020. Tropical forest and peatland conservation in Indonesia: Challenges and directions. People Nat 2 (1): 4-28. DOI: 10.1002/pan3.10060

Hergoualc'h K, Carmenta R, Atmadja S, Martius C, Murdiyarso D, Purnomo H. 2018. Managing peatlands in Indonesia: Challenges and opportunities for local and global communities. Center Int For Res 25: 2018. DOI: $10.17528 /$ cifor/006449

Hine C. 2000. Virtual Ethnography. Sage Publisher, London.

KLHK. 2018. Managing Peatlands to Cope with Climate Change: Indonesia's Experience.

Lampela M, Jauhiainen J, Sarkkola S, Vasander H. 2017. Promising native tree species for reforestation of degraded tropical peatlands. For Ecol Manage 394: 52-63. DOI: 10.1016/j.foreco.2016.12.004

Miettinen J, Shi C, Liew SC. 2016. Land cover distribution in the peatlands of Peninsular Malaysia, Sumatra and Borneo in 2015 with changes since 1990. Global Ecol Conserv 6: 67-78. DOI: 10.1016/j.gecco.2016.02.004
Miles L, Ravilious C, Garcia-Rangel S, de Lamo X, Darie G, Lewis Simon. 2017. Carbon, biodiversity and land-use in the Central Congo Basin Peatlands. Global Change Biol 18 (1): 164-178.

Murdiyarso D, Suryadiputra IN, Wahyunto. 2004. Tropical peatlands management and climate change: A case study in Sumatra, Indonesia. Wise Use of Peatlands. Proceedings of the 12th International Peat Congress, Tampere, Finland, 6-11 June 2004. (January): 698-706.

Nurdiana A, Setiawan Y, Pawitan H, Budi L, Ayu P. 2016. Land changes monitoring using MODIS time-series imagery in peat lands areas, Muaro Jambi, Jambi Province, Indonesia. Procedia Environ Sci 33: 443-449. DOI: 10.1016/j.proenv.2016.03.095

Nurjanah S, Octavia D, Kusumadewi F. 2013. Identifikasi Lokasi Penanaman Kembali Ramin (Gonystylus bancanus Kurz) Di Hutan Rawa Gambut Sumatera Dan Kalimantan. Pusat Penelitian dan Pengembangan Konservasi dan Rehabilitasi, Badan Penelitian dan Pengembangan Kehutanan. Bogor. [Indonesian]

Nuroniah HS, Tata HL, Mawazin, Martini E, Dewi S. 2021. Assessment on the suitability of planting non-native peatlands species Falcataria moluccana (Miq.) Barneby \& Grimes in Rewetted Peatlands. Sustainability 13 (13): 7015. DOI: 10.3390/su13137015

Page SE, Rieley JO, Banks CJ. 2011. Global and regional importance of the tropical peatland carbon pool. Global Change Biol 17 (2): 798818. DOI: $10.1111 /$ j.1365-2486.2010.02279.x

Page SE, Rieley JO, Shotyk ÒW, Weiss D. 1999. Interdependence of peat and vegetation in a tropical peat swamp forest. Philos Trans R Soc Lond B Biol Sci 354 (1391): 1885-1897. DOI: 0.1098/rstb.1999.0529

Prasetyo LB, Dharmawan AH, Nasdian FT, Ramdhoni S. 2016. Historical forest fire occurrence analysis in Jambi Province during the period of 2000-2015: Its distribution and land cover trajectories. Procedia Environ Sci 33: 450-459. DOI: 10.1016/j.proenv.2016.03.096

Pratiwi SW, Hastuti KP, Alviawasti E, Rahman AM. 2021. Peatland economic revitalization program based on community participation in Jarenang Village, Kuripan District, Barito Kuala Regency, South Kalimantan. Proceedings of the 2nd International Conference on Social Sciences Education (ICSSE 2020) 525: 394-398. DOI: 10.2991/assehr.k.210222.065

Rangkuti F. 2013. SWOT-Balanced Scorecard. Gramedia Pustaka Utama, Jakarta. [Indonesian]

Scolozzi R, Schirpke U, Morri E, D’Amato D, Santolini R. 2014. Ecosystem services-based SWOT analysis of protected areas for conservation strategies. J Environ Manage 146: 543-551. DOI: 10.1016/j.jenvman.2014.05.040

Syahza A, Suswondo, Bakce D, Nasrul B, Wawan, Irianti M. 2020. Peatland policy and management strategy to support sustainable development in Indonesia. J Physics Conf Ser 1655: 012151. DOI: 10.1088/1742-6596/1655/1/012151

Syaufina L, Hafni AF. 2018. Variability of climate and forest and peat fires occurrences in Bengkalis Regency, Riau. Jurnal Silvikultur Tropika 9 (1): 60-68. DOI: 10.29244/j-siltrop.9.1.60-68

Tamin RP, Ulfa M, Saleh Z. 2019. Identifikasi potensi pohon induk pada tegakan tinggal Taman Hutan Raya Orang Kayo Hitam pasca kebakaran hutan. Jurnal Ilmiah Ilmu Terapan Universitas Jambi 3 (1): 10-17. [Indonesian]

Tamin RP, Ulfa M, Saleh Z. 2021. Identifikasi potensi permudaan alam di hutan rawa gambut Taman Hutan Raya Orang Kayo Hitam Provinsi Jambi Pasca Kebakaran Hutan. Al-Kauniyah: Jurnal Biologi 14 (1): 42-51. DOI: 10.15408/kauniyah.v14i1.15136 [Indonesian]

Tata HL, Pradjadinata S. 2016. Native species for degraded peat swamp forest rehabilitation. Jurnal Silvikultur Tropika 07 (3): 80-82. DOI: 10.29244/j-siltrop.7.3.S80-S82

Thoha AS, Saharjo BH, Boer R, Ardiansyah M. 2018. Strengthening community participation in reducing GHG emission from forest and peatland fire. IOP Conference Series: Earth and Environmental Science 122 (1): 0-10. DOI: 10.1088/1755-1315/122/1/012076

Wahyunto W, Nugroho K, Ritung S, Sulaeman Y. 2014. Indonesian peatland map: Method, certainty, and uses. Mapping problem soils in Indonesia

Ward C, Stringer LC, Warren-Thomas E, Agus F, Crowson M, Hamer K, Hariyadi B, Kartika WD, Lucey J, Mcclean C, Nurida NL, Petorelli N, Pratiwi E, Saad A, Andriyani R, Ariani T, Sriwahyuni H, Hill JK. 2021. Smallholder perceptions of land restoration activities: Rewetting tropical peatland oil palm areas in Sumatra, Indonesia. Regional Environ Change 21 (1): 1-17. DOI: 10.1007/s10113-02001737-z/Published

Wijedasa LS, Sloan S, Page SE, Clements GR, Lupascu M, Evans TA. 2018. Carbon emissions from South-East Asian peatlands will 
increase despite emission-reduction schemes. Global Change Biol 24 (10): 4598-4613. DOI: $10.1111 / \mathrm{gcb} .14340$

Wösten JHM, van den Berg J, van Eijk P, Gevers GJM, Giesen WBJT, Hooijer A, Idris A, Leenman PH, Rais DS, Siderius C, Silvius MJ, Suryadiputra N, Wibisono IT. 2006. Interrelationships between hydrology and ecology in fire degraded tropical peat swamp forests. Int J Water Resour Develop 22 (1): 157-174. DOI: 10.1080/07900620500405973

Wulandari C, Bintoro A, Rusita, Santoso T, Duryat, Kaskoyo H, Erwin, Budiono P. 2018. Community forestry adoption based on multipurpose tree species diversity towards to sustainable forest management in ICEF of University of Lampung, Indonesia. Biodiversitas 19 (3): 1102-1109. DOI: 10.13057/biodiv/d190344

Wulandari C, Inoue M. 2018. The Importance of social learning for the development of community based forest management in Indonesia: The case of community forestry in Lampung Province. Small-scale For 17 (3): 361-376. DOI: 10.1007/s11842-018-9392-7
Wulandari C, Kurniasih H. 2019. Community preferences for social forestry facilitation programming in lampung, Indonesia. For Soc 3 (1): 114-132. DOI: 10.24259/fs.v3i1.6026

Wüst R, Rieley J, Page S, van der Kaars S, Wang W-M, Jacobsen G, Smith A. 2007. Peatland evolution in Southeast Asia during the last 35,000 cal years: Implications for evaluating their carbon storage potential. Trop Peatland (June): 27-29.

Xu J, Morris PJ, Liu J, Holden J. 2018. PEATMAP: Refining estimates of global peatland distribution based on a meta-analysis. Catena 160: 134-140. DOI: 10.1016/j.catena.2017.09.010

Yam JH. 2020. Manajemen Strategi: Konsep dan Implementasi. Nas Media Pustaka, Indonesia. [Indonesian]

Yule CM. 2010. Loss of biodiversity and ecosystem functioning in IndoMalayan peat swamp forests. Biodiv Conserv 19 (2): 393-409. DOI: 10.1007/s10531-008-9510-5 